\title{
Privacy and Exemplarity in Gianlorenzo Bernini's Cornaro Chapel
}

\author{
Maarten Delbeke
}

This paper proposes a case study to test the relevance of architecture for our understanding of early modern notions of privacy. ${ }^{1}$ At the Centre for Privacy Studies, privacy is understood as shaping relationships on different levels, from the individual body to society, entities each with their own spatial presence and relationships. To what extent is the spatial component of privacy also a matter of architecture, understood as the intentional design of the elements that define space and materialise its limits? To approach this question I will read the Cornaro Chapel, designed by Gianlorenzo Bernini for Federico Cornaro in $\mathbf{1 6 4 7}^{-52}$, as a site where an intimate and interior experience, set in a private space, is made public for the purpose of edification and devotion. I want to reflect on the role of architecture in the process of transforming the private into a public display, by establishing its spatial conditions and making them explicit. This reading is framed by a brief foray into statements about the private and public persona in a particular and historically important treatise on religious art, the Discorso intorno alle immagine sacre e profane written by Gabriele Paleotti and first published in 1582 . Paleotti attributes a public dimension to religious art, as its subject matter transcends the intentions and ambitions of the private individual. I propose to read the Cornaro Chapel as a sophisticated device that performs the negotiations between these two dimensions. By reading the Cornaro Chapel as a site of conspicuous patronage where an intimate and interior moment is put on public display, this essay hopes to offer some suggestions about how architecture negotiates between the private and public in religious art and to provide some understanding of how the spatial component of privacy can be a matter of architecture.

1 This essay is the keynote lecture delivered at Early Modern Privacy - Notions, Spaces and Implications, Copenhagen, 9-11 April 2019. I am grateful to the editors for welcoming this preliminary work in their volume and for their patience. 
Over the course of the sixteenth and seventeenth centuries, confessional conflicts and reform movements prompted theoretical debates about religious art. One important Catholic strand in these debates was intended to provide guidelines for priests and patrons about the appropriate subject matter, use, and display of religious art. Formulated in the wake of the Council of Trent, it looked at religious art from a functional perspective, valuing works of art according to their ability to achieve their goals: to instruct and educate the people, to instill devotion, and to glorify God. From this perspective, art fulfills its function thanks to its choice of subject matter, the context of display, and its appeal to the emotions of the viewing subject. Many late sixteenthand seventeenth-century texts of various genres characterise the visual arts by their capacity to express inner emotions through movements of body and face, the so-called affetti. Such forms of expression should appeal to viewers, make them experience similar emotions, and in so doing move them to virtue or devotion, instigating a mimetic process. Treatises on art describe and theorise this process and identify it as the essence and purpose of poetry, painting, and sculpture. ${ }^{2}$

To what extent does the process by which religious art affects its viewers imply a transition or negotiation between a private and a public dimension? The emotions on display in religious art are both intimate and interior. They become manifest at events that sometimes take place in public but often occur in spaces of solitude and that can be characterised to some extent as private: the desert, the home, the bedroom, or the cell. But in a public context too emotions always retain an interior component, since their ultimate locus is the heart. ${ }^{3}$ At the same time, religious art, whether in word or image, mobilises these emotions rhetorically, with the intention to reach and affect an audience. Religious art involves a transition from a singular, private realm to a shared, public one.

In order to test whether this transition was discussed in the post-Tridentine Catholic discourse on images and whether that discussion drew on notions of the private, the Discorso intorno alle immagine sacre e profane was mined for the occurrence of the so-called 'priv-' words. ${ }^{4}$ Repeated searches yielded 17

2 For an effective overview of the extensive literature on these topics, see Strünck Ch., "Die Kunsttheorie des Barock", in Brassat W. (ed.), Handbuch Rhetorik der bildenden Künste (Berlin - Boston: 2017) 435-45o.

3 See Treffers B., Een hemel op aarde: Extase in de Romeinse barok (Nijmegen: 1995).

4 Paleotti Gabriele, Discorso intorno alle immagini sacre e profane (Bologna, Alessandro Benacci: 1582). I have used the pdf available at http://www.memofonte.it/home/files/pdf/ 
occurrences, not all relevant. ${ }^{5}$ Relevant occurrences (mainly of 'privato') bear mostly on two issues: whether it is appropriate to keep paintings with dubious subject matter in the private house and whether rulers have the right to have their statue erected and under what conditions. This question can be related to a third issue where 'privato' occurs, concerning when and how it is legitimate to attach one's name publicly to a book or a work of art.

The first issue, the appropriateness of paintings with dubious subjects, leads Gabriele Paleotti to distinguish the more public and more private zones in the private house and to relate this distinction to the potential effect of art works. The paintings Paleotti discusses here are portraits of individuals of dubious morality, such as emperor Nero. This is how such portraits should be treated:

[...] e perché la casa ha alcuni luoghi come publici et altri privati, potrassi più facilmente concedere ad una persona letterata e di giudicio di poterle tenere ad uso buono in luoghi privati per sua commodità, che nei luoghi publici, come nelle loggie, sale e cortili delle case, dove capitano altre persone, le quali non avendo il concetto che ha il padrone, ma giudicando essi secondo l'ordinaria condizione delle imagini, che siano fatte per onorare, possono insieme restare offesi che l'onore e dignità sia attribuita a persone indegne et infami. ${ }^{6}$

And because the house has some places that are public and some that are private, one could more easily concede to a literate and judicious person to keep [these paintings] in good use in private places, for his convenience, rathert han in public places, like loggias, halls, and courtyards of the houses, where other persons convene, who do not have the same understanding the patron has; but judging according to the normal condition of images, [which is that they are] made to honour [the subject], [these other persons] could remain offended that this honour and dignity is attributed to unworthy and infamous people.

Paleotti suggests that in the public parts of the house images will be viewed by many and according to common expectations: that the painting is there to convey honour to the person represented and to teach viewers valuable lessons in history and morality. Paintings of a more ambiguous purpose - as when

scritti_paleotti.pdf, accessed on 4 April 2021. Pagination refers to this document, which is drawn from Barocchi P., Trattati d'arte del Cinquecento, vol. 2 (Bari: 1961) 117-517.

5 The search yielded, for instance, mentions of the adverb 'priva' that were irrelevant.

6 Paleotti, Discorso 310. Translations are my own. 
one keeps a portrait of Nero out of sheer curiosity - should be kept away from the public eye. Paleotti compares paintings of illicit subjects to the kind of weapons that, because they are so dangerous, should not be handled by anyone, but only serve those who are expert and trained in it'. These images should be held in 'private rooms and separate spaces.'

The problematic of the dubious portrait points towards degrees of privacy in the house. It suggests that these degrees assist in regulating the power of images, a power they exert thanks to the expectations they arouse. These expectations direct how paintings should be kept. When subject matter requires context and expert judgment, paintings cannot be left to their own devices. ${ }^{8}$

The expected effect of works of art is also at stake in the most dense cluster of priv-words in Paleotti's Discorso, the discussion of the portrait of the ruler. Paleotti devotes a considerable section of his treatise to the question of whether it is legitimate to erect statues to rulers and to do so during their lifetime. Commissioning and erecting such statues is a long-established practice and a matter of equally long-standing debate. ${ }^{9}$ As a means of justification, Paleotti distinguishes the public from the private persona of the ruler and attaches the statue to the first:

Alla publica appartengono tutte le cose che toccano la maestà del grado, la administrazione de'popoli e debita esecuzione della giustizia per conservazione della religione, della pace e della disciplina de' costumi, ad utilità comune, essendo ufficio di persona publica. [...] Alla privata appartengono tutte l'altre cose che ad essi come uomini possono essere communi, o siano interne, come i pensieri, i desiderii e disegni loro, in quanto sono alieni dall'officio regale, o siano esterne, come sono le azzioni domestiche non dirizzate al governo universale. ${ }^{10}$

To the public persona [of the ruler] belong all things that touch upon the majesty of the station, the administration of the people and the due execution of justice so as to maintain religion, peace, and the discipline

7 Ibidem, 311.

8 This distinction recalls Paolo Cortesi's discussion of the appropriate interior decoration of the residence of the cardinal, which also reflects the degree of privacy of various rooms. See Weil-Garris K. - D'Amico J., "The Renaissance Cardinal's Ideal Palace: A Chapter from Cortesi's De Cardinalatu", in Millon H.A. (ed.), Studies in Italian Art and Architecture, 15th through 18th Centuries 35 (1980) 45-123.

9 Delbeke M., The Art of Religion. Sforza Pallavicino and Art Theory in Bernini's Rome (Aldershot: 2012) 97-113.

10 Paleotti, Discorso 324. 
of the customs, as it is an office of the public person [...] To the private person belong all the other things that to them, as human beings, might be common, either internally, such as their thoughts, desires, and plans, as far as they are foreign to the regal office, or externally, such as domestic actions that are not directed towards universal government.

The statue is an attribute that conveys majesty, authority, and power, and contributes to the ruler's public office. Only under this condition is the statue legitimate. Attached to the private persona, the statue becomes a matter of vanity and pride. This distinction appears to be quite clear cut and fits into a long tradition of thought about the relationship between the public and private persona of the ruler, developed for instance in mirrors of princes. ${ }^{11}$ Nonetheless, Paleotti attributes astonishing power to the statue and sees it as an object capable of projecting the majesty of the ruler's office in public space. Precisely this power requires a careful distinction between the public and private persona, since it is easily misdirected. Just as the expectations regarding paintings impose restrictions on where they should be displayed, so the private and public persona of the ruler each define specific conditions for their respective representation. The 'public statue' pertains to the 'supreme dignity, and it is as it were part of royal magnificence [...]', not to 'the other things that to them, as human beings, might be common. Only the first dimension is properly public. ${ }^{12}$

The questions of proper display and the distinction between a public and private dimension of the artwork meet in a related problem, which concerns the question of attributing one's name to a commission. At the end of the Discorso, Paleotti discusses whether patrons should attach their name or arms to sacred paintings. As part of this problematic, Paleotti ponders the appropriateness of publicising a religious foundation by means of words, book, or painting. His discussion indicates how, thanks to its function, religious painting transcends private intentions. As expected, Paleotti warns against boasting about one's foundations, especially when it comes to writing, since print 'as a public and permanent matter, is exposed to all, and will receive harsher notice from judges.' ${ }^{13}$ Still, Paleotti continues, sayings and writings about such foundations are ultimately a private matter 'that depends on the will of each and

11 See Gaylard S., Hollow Men: Writing, Objects, and Public Image in Renaissance Italy (New York: 2013).

12 Paleotti, Discorso 324.

13 Ibidem, 486. 
every one, and are composed, changed, and revoked as pleases us.14 Under such circumstances, a signature has a particular function, as it literally authorises the work. This mechanism of conveying authority is not relevant when it comes to sacred painting. Since such works are dedicated to God, 'they escape our authority $[\ldots]$ and can no longer be transferred to private use, since they are already sacred, they are in the churches, they are for the teaching of the people, and they serve the divine glory. So for their subject, mystery, place, and purpose they should not be regulated with the measure of other things. ${ }^{15}$ Paleotti thus suggests that a painting of sacred subject matter transcends the private interests that may have occasioned it, since it forms part of an economy different to that of the private writings of individuals and the potentially doubtful intentions that motivated them. The sacred painting becomes detached from volatile private desires and expressions. It enters the public sphere as subjected to the imperative of divine glory.

This imperative establishes an analogy between the statue of the ruler and the sacred painting. Both cases define a distinction between the private and the public sphere, not just because each sphere pertains to either the private or public persona of the ruler or patron, but also because both the ruler's statue and the sacred painting convey an authority that has its source beyond the circumstances of its creation and display - in both cases, ultimately, God. Taking Paleotti's point further, the author suggests that in sacred paintings the private becomes public thanks to its function and effect. Because there is a general and important truth at stake, the sacred painting detaches itself from the private individuals engaged in its production, such as the patron and the artist. With this stance, Paleotti circumvents the paradox of religious art outlined at the outset: that in order to be effective, such art needs to translate an experience from a singular, private realm to a shared, public one. In Paleotti's view, this transition shifts expectations and defines obligations: the representation is now subsumed by the realm of divine authority, and should conform to what the viewer expects.

Interior Space and the Architecture of the Cornaro Chapel

The Cornaro Chapel, designed and built by Gianlorenzo Bernini and his workshop for Cardinal Federico Cornaro, is situated in the left transept of the Santa Maria della Vittoria Church in Rome. The fame of the chapel rests in

\begin{tabular}{ll}
\hline 14 & Ibidem. \\
15 & Ibidem.
\end{tabular}


large part on Bernini's sculptural group of the Transverberation of Saint Teresa. The monumental altarpiece of the chapel presents the viewer with the effigy of the languishing mystic, seemingly held aloft by the smiling angel who is about to transpierce her heart with a golden arrow. The sense of elevation is enhanced by Bernini's audacious move to make the sculptural group seemingly baseless. ${ }^{16}$ Because of its depiction of total abandonment, with her senses 'closed to the world', the swooning saint has drawn vehement and mixed critical responses, many of which point - admiringly or derisively - to the astonishing intimacy with which the viewer is presented. ${ }^{17}$ Famously, Charles de Brosses quipped: 'if this is divine love, I know all about it'; Luigi Scaramuccia, a contemporary painter and critic far more in tune with Bernini's intentions, wrote that 'just as she [Teresa] is seen to be in ecstasy, so she makes him who gazes fall into ecstasy by virtue of the excellence of that great master who made her', exploiting the affinity of aesthetic pleasure with religious ecstasy. ${ }^{18}$

In order to achieve this effect, Bernini's sculptural group evokes a passage from Teresa's autobiography, The Book of Her Life (first published in 1562), where she describes experiencing the at once unbearable and sweet pain of being deeply transpierced by divine love with an angel at her side. This experience soon became an emblematic part of Teresa's iconography and her claim to sanctity. The account of the transverberation was included in other biographies and from there into the bull of her canonisation. The event is shown in Matthias Greuter's famous print celebrating the 1622 canonisation of St. Teresa at St. Peter's. ${ }^{19}$ While the autobiographical passage itself is quite thin on details about where the transverberation took place, it is believed to have happened in April 156o in a noble palace. Still, in the visual tradition the event is situated in a variety of more or less private rooms, ranging from cells through chapels to church interiors.

In the Cornaro Chapel, the question of the spatial setting of the transverberation informs many of Bernini's architectural decisions, especially as regards the niche of the sculptural group. The niche is designed on an oval ground plan, placed transversally, with the short axis determining the depth

16 Barry F., "Im/material Bernini”, in Levy E. - Mangone C. (eds.), Material Bernini (London: 2016) 39-67; Pierguidi S., Pittura di marmo. Storia e fortuna delle pale d'altare a rilievo nella Roma di Bernini (Florence: 2017) 127-131.

17 Quotation from Levy E., "Gianlorenzo Bernini's Cornaro Chapel", in Snodin M. Llewellyn N. (eds.), Baroque: Style in the Age of Magnificence, 1620-180o (London: 2009) 96-117.

18 Bolland A., "Alienata da'sensi: Reframing Bernini's S. Teresa”, Open Arts Journal 4 (Winter 2014-2015) 134-157. Bolland's emphasis on the importance of 'witnessing' in the chapel has been crucial for the reading advanced here.

19 On the iconography and its impact on the design of the chapel, see Lavin I., Bernini and the Unity of Visual Arts (New York: 1980). 
of the space. The paired marble columns of the frontispiece are placed along the perimeter of the oval, seemingly bending the pediment in the process. The taut points of the pieces of cornice that jut out over the double columns suggest the tension generated by this movement and convey the impression that the niche discloses its interior to the viewer. As such, the niche becomes a metaphor for the body of Teresa, whose heart is being opened by the arrow of divine love. This metaphor is further reinforced by the contrast between the niche that discloses its interior to the outside world and Teresa's body, which is almost entirely shrouded - as if the niche helps to explain what happens inside this mass of folding clothes. At the same time, the undulation of the pediment caused by the bend in the plan generates a form that recalls that of the human heart, again referring to the hidden site of the reverberation. This formal echo is emphasised by the image of the flaming heart at the centre of the frieze in the entablature. In a surprisingly straightforward way, the architecture of the niche helps the viewers to think about and relate to Teresa's intimate experience. With its architectural scenography, the niche expresses the notion of the interior. As an architectural body under the stress of transformation - the bending outwards of the structure of the pediment - it conveys what happens in the mysterious and rigorous body it contains.

The crucial role of the architecture of the niche in communicating Teresa's mystical experience recalls the prominent use of architectural metaphors in mystical writings. Several authors have drawn attention to the frequency of architectural similes in texts that aim to describe and communicate mystical experiences that are essentially beyond the grasp of language. As Barbara Kurtz has argued, this phenomenon is due to the large stock of available architectural similes in Scripture as well as to their easy mnemonic use. After all, the art of memory itself is deeply imbued with architectural thought, since it structures memories in architectural spaces. But, as Kurtz writes, there is also a more structural foundation for architectural similes in mystical writing:

As enclosure, the metaphor effectively expresses interrelated dualities basic to mystical experience: body-soul, outer-inner, carnal-spiritual. As designed edifice, the figure structuralizes delicate descriptions that without its use could lapse into an inchoate outpouring of sentiments or assertions scarcely comprehensible to the uninitiated reader or listener. And as Scripture-based allusion, the figurative edifice links personal experience with divine condescension. ${ }^{20}$ 
Following Kurtz, the architectural simile plays a key role in making public what happens in the most private recesses of the mystic's heart and soul, as it renders the relationship and tension between inside and outside tangible and explicit, provides a structure and a language common to the mystic and the uninitiated, and establishes typological relationships between the individual case of the mystic and key moments of sacred history, by referring to such structures as the tabernacle, the thalamus, or the temple.

Like many mystics, Teresa avidly used architectural metaphors, perhaps most famously in the Interior Castle, structured around the image of the seven castles of the soul, a sequence of buildings made from ever more precious matter which the apprentice must seek to penetrate. Bernini may have been aware of such literary devices, if only because they were commonplace enough to be generally available. But, as we have seen, the architectural device of the niche operates as an image for the body of Teresa through its visual and architectural presence, regardless of any precise literary reference. If Bernini engaged references, they would be drawn from architecture rather than literature. The architecture of the niche is of the Corinthian order, based on such examples as the Temple of Venus Genetrix on the Roman Forum. Today only three columns and a piece of architrave of the temple are visible, but the building was known from ancient texts and to Renaissance architects. Andrea Palladio, for instance, proposed a detailed reconstruction of the building in his Four Books of Architecture, published in $1570 .{ }^{21}$ Bernini may have had this model in mind for the design of the niche as it would translate elements associated with an ancient female deity to a female Catholic saint. As a protectress of the family, Venus Genetrix seems appropriate for the foundress of the Discalced Carmelites.

The entablature in the Cornaro Chapel employs a similar sequence of architrave, frieze, and cornice as the temple [Fig. 16.1]. The architrave presents an elaborate sequence of fasciae and mouldings. The acanthus rinceau of the frieze is quite similar to the Venus Genetrix, and frames the flaming heart at its centre. The cornice consists of dentils and a cyma recta, under modillions framing rosettes and supporting the corona. In a subtle play, only the cornice segments of the upper part of the pediment are crowned with the customary cyma recta, their offsets with the base creating the taut corners of the frontispiece.

If the exterior frame of the niche follows established models of the Corinthian order quite closely, in the interior Bernini deliberately manipulated

21 Palladio Andrea, I quattro libri dell'architettura (Venice, Dominico de'Franceschini: 1570) book IV, XXXI, 128-133, referred to as the Tempio di Nettuno. 


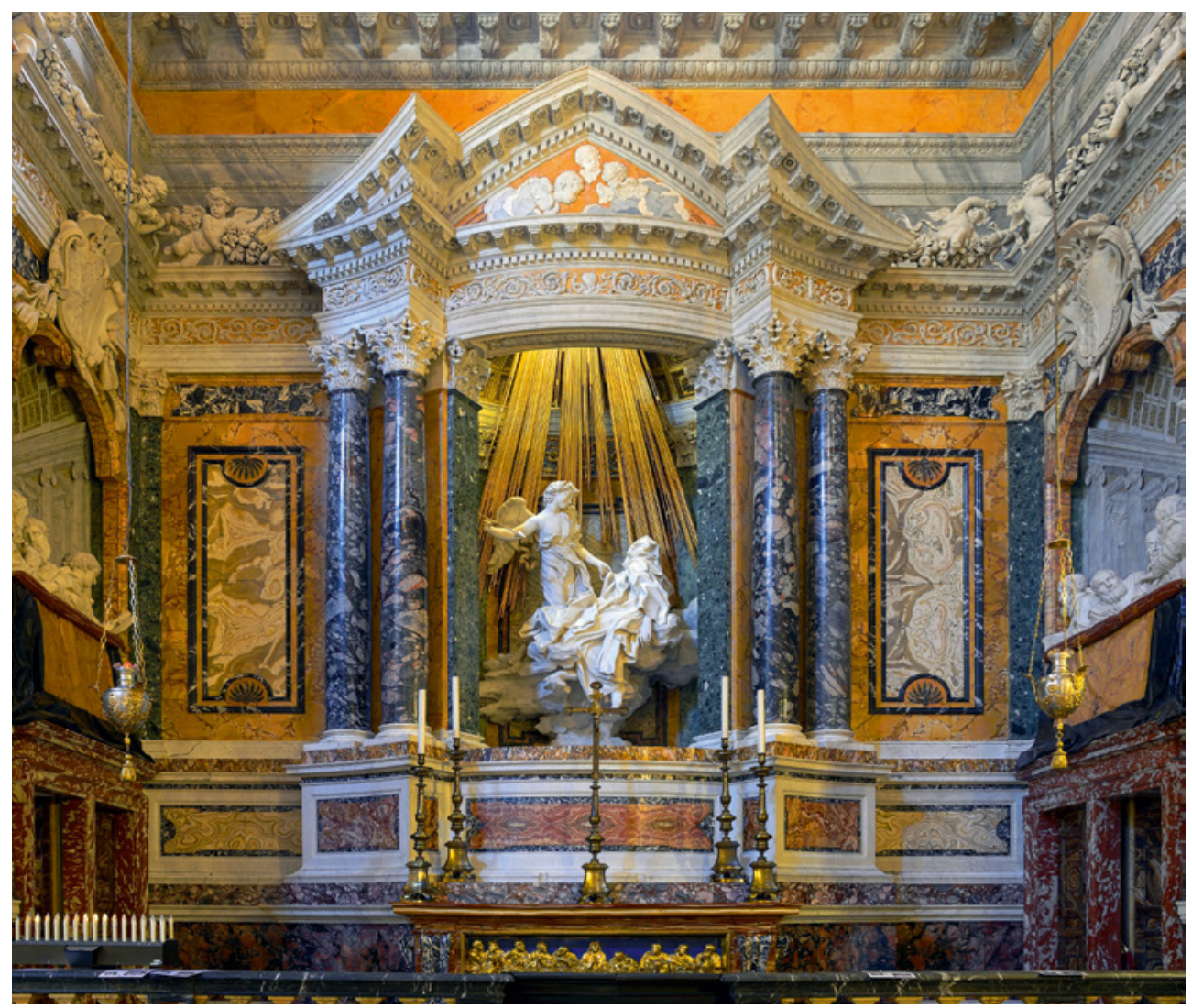

FIGURE 16.1 Gianlorenzo Bernini, The niche of the Cornaro Chapel with the Transverberation of St. Teresa, Santa Maria della Vittoria, Rome, $1647-165^{2}$ PUBLIC DOMAIN, WIKIPEDIA COMMONS

the order and, with that, the expectations of the viewer. Generally, the architectural order - the sequence of column, capital, and entablature - follows the same sequence in the interior as the exterior of a building, since it represents both on the inside and the outside a construction supporting the roof and carrying its load to the columns. Often the exterior and interior order are not aligned in section. Famously, the interior cornices of Donato Bramante's Tempietto in Rome sit higher and closer to each other than the exterior ones, to compensate visually for the diminished diameter of the interior space compared to the exterior. ${ }^{22}$ Only careful comparison aided by measuring or drawing

22 See Serlio Sebastiano, Il terzo libro [...] nel quale si figurano, e descrivono le antiquità di Roma [...] (Venice, Francesco Marcolino da Forli: 1540) 44. 
reveals such discrepancy. In the case of the Cornaro niche, by contrast, the exterior and interior are visible simultaneously. Bernini seizes on this condition to manipulate the architectural composition. The exterior would suggest that the interior dome rests on the cornice, as is customary. Yet in the interior of the niche only the architrave, the lower part of the entablature, is maintained; frieze and cornice are omitted. This lends the remaining element considerable ambiguity. The elaborate profile of the exterior architrave is rehearsed within and suggests the customary sequence of architrave, frieze, and cornice, yet on a smaller scale. At the same time, between the interior Corinthian capitals sit panels with acanthus rinceaus recalling the motif of the exterior frieze. Crowning these panels, the interior architrave acts as a cornice, the appropriate element to support the dome. In this reading, the exterior architrave becomes the interior cornice, and Bernini flips the entablature around.

Eliminating the better part of the entablature in the interior of the niche lowers the dome relative to the exterior and makes it visible to the viewer, to whom it would otherwise have remained hidden behind the pediment. While rendering the scale of the interior more intimate, the lowered gilded dome also intensifies the flood of heavenly light over Teresa, emphasising the action of divine grace on the saint. At the same time, the subtle manipulation of the architectural system of the niche signals that while exterior and interior are part of the same system, they follow a different order, the exterior reminiscent of the canonical buildings of antiquity, the interior unusual and therefore apposite for extraordinary events. The architrave-turned-cornice literally weaves these two conditions together, while pointing out their difference. Bernini would use the same device for the main altar of the Jesuit novitiate church of Sant'Andrea al'Quirinale, again to establish an architectural connection between an interior transformation and its external expression, now the martyrdom of St. Andrew. Here an additional layer is added by casting the pediment over the altar as a model of a sectioned dome, with a stucco effigy of St. Andrew escaping through its oculus. The elaborate profile of the pediment rehearses the entablature supporting the dome of the church, which suggests a two-stage transition from interior to exterior: between the niche of the altar and its architectural frontispiece, and the frontispiece and the space of the church. ${ }^{23}$

23 Barry, “Im/material Bernini” 57-6o. 


\section{Conclusion: Architecture and Privacy?}

The passages from Paleotti discussed at the outset can be read as negotiations of a fault line which does not just modulate expectations but also entails obligations. These obligations concern the calibration of the private against the public persona with regard to a work of art. As we have seen, Paleotti presents the sacred and the magnificent as virtues whose very presence overrides private concerns. Considerations such as one's individual authority or reputation, which call for attaching one's name to a work or publicising one's views, become not just futile but also counterproductive and even dangerous when transferred into the public realm of sacred subject matter or royal representation. Conversely, only in the most private sphere can works of art be freed of their moral or religious obligations towards society.

At the Cornaro Chapel, the lodges on either side of the Transverberation display effigies of eight male members of the family of its patron, Federico Cornaro. The men are displayed under a giant and animated coat of arms, in one of the most conspicuous funerary chapels built in seventeenth-century Rome. If anything, Paleotti's concerns over the broadcasting of patronage would apply here. This condition allows us to read the chapel as a negotiation of the publicness and privateness we discerned in his Discorso. The illusionistic spaces where the Cornaros are seated recall loggias or andrones, parts of private palaces, not religious spaces. Crucially, the Cornaros look outward from these interiors, into the transept of the church. There they are lined up as a gallery of illustrious men, living proof of the virtue and success of the Cornaro lineage, examples worthy of emulation and driven by lofty aspirations. ${ }^{24}$ Teresa, too, is an exemplum, her floating foot a dangling invitation to adherence. ${ }^{25}$ Yet, as few commentators have failed to observe, the saint and the Cornaro-men remain in separate realms, with nothing suggesting actual interaction between the patrons and the drama unfolding in the niche. The event of the Transverberation is presented as a revelation of a most private experience, disconnected from the surrounding space. If the chapel inscribes the subjects of both the Cornaros and Teresa in the economy of public representation, they are each framed in their appropriate realm, the palace for the noble family, and the niche for the saint.

24 See the discussion in Barcham W.L., Grand in Design. The Life and Career of Federico Cornaro, Prince of the Church, Patriarch of Venice and Patron of the Arts (Venice: 2001) $366-382$.

25 Treffers, Een hemel op aarde $163^{-165}$. 
As a site of conspicuous patronage that makes a sophisticated public display of an intimate and interior moment, the Cornaro Chapel illustrates how architecture helps to negotiate the transition from the experiences and ambitions of the private individual - both Teresa and Federico Cornaro - to a representation laying claim to a higher authority. The sophisticated use of architecture allows the private to participate in the economy of public representation while anchoring the display in a suggestion of interiority or privateness. The means mobilised are architectural metaphors like the opening niche, design systems like the architectural orders, and forms of architectural scenography like the illusionistic loggias. If space is the field where privacy becomes articulated, and architecture is the articulation of space, then the chapel offers an example of how architecture is activated to render the transition from the private to the public productive in the creation of sacred art.

\section{Bibliography}

Barcham W.L., Grand in Design. The Life and Career of Federico Cornaro, Prince of the Church, Patriarch of Venice and Patron of the Arts (Venice: 2001).

Barocchi P. (ed.), Trattati d'arte del Cinquecento, vol. 2 (Bari: 1961).

Barry F., "Im/material Bernini", in Levy E. - Mangone C. (eds.), Material Bernini (London: 2016) 39-67.

Bolland A., "Alienata da'sensi: Reframing Bernini's S. Teresa”, Open Arts Journal 4 (Winter 2014-2015) 134-157.

Delbeke M., The Art of Religion. Sforza Pallavicino and Art Theory in Bernini's Rome (Aldershot: 2012).

Gaylard S., Hollow Men: Writing, Objects, and Public Image in Renaissance Italy (New York: 2013).

Kurtz B., "The Small Castle of the Soul: Mysticism and Metaphor in the European Middle Ages", Studia Mystica 15 (1992) 19-39.

Lavin I., Bernini and the Unity of Visual Arts (New York: 1980).

Levy E., "Gianlorenzo Bernini's Cornaro Chapel”, in Snodin M. - Llewellyn N. (eds.), Baroque: Style in the Age of Magnificence, 1620-1800 (London: 2009) 96-117.

Paleotti Gabriele, Discorso intorno alle immagini sacre e profane (Bologna, Alessandro Benacci: 1582).

Palladio Andrea, I quattro libri dell'architettura (Venice, Dominico de'Franceschini: 1570).

Pierguidi S., Pittura di marmo. Storia e fortuna delle pale d'altare a rilievo nella Roma di Bernini (Florence: 2017). 
Serlio Sebastiano, Il terzo libro [...] nel quale si figurano, e descrivono le antiquità di Roma (Venice, Francesco Marcolino da Forli: 1540).

Strünck Ch., "Die Kunsttheorie des Barock", in Brassat W. (ed.), Handbuch Rhetorik der bildenden Künste (Berlin - Boston: 2017) 435-450.

Treffers B., Een hemel op aarde: Extase in de Romeinse barok (Nijmegen: 1995).

Weil-Garris K. - D’Amico J., "The Renaissance Cardinal's Ideal Palace: A Chapter from Cortesi's De Cardinalatu", in Millon H.A. (ed.), Studies in Italian Art and Architecture 35 (1980) 45-123. 